DE DE GRUYTER OPEN
Journal of Intercultural Management

Vol. 7, No. 3, September 2015, pp. 101-117

DOI 10.1515/joim-2015-0023

Aleksandra Grobelna ${ }^{23}$

Gdynia Maritime University

\title{
Intercultural Challenges Facing the Hospitality Industry. Implications for Education and Hospitality Management
}

\begin{abstract}
Hospitality organizations which are increasingly operating internationally create real challenges for their employees and managers to interact and effectively work with people from different cultural environments. Many problems may relate to intercultural communication between managers and employees as well as between employees and hotel guests from different cultural backgrounds. Therefore, the issue of intercultural communication has recently had an increasing reach in the hospitality industry.

Cultural awareness, sensitivity and understanding of cultural differences should be perceived as a critical issue for business success. Therefore, the following questions still need answers from both academics and the business: What kind of challenges does the hospitality industry face in view of the multicultural diversity of its markets? What kind of managers' skills and abilities, particularly in the case of entry-level managers, are strongly needed today to manage effectively multicultural hospitality workforce? And how may educational programs influence intercultural competence development of tourism and hospitality students to interact effectively in a multicultural environment. The aim of the study is to show that cultural diversity of hotel employees and guests may create unique challenges of cross-cultural service encounters, which may provide an opportunity for service differentiation.

The research problem is to find answers to the questions: how may the challenges that emerge from cross-cultural interactions become a source of hotel competitiveness and how may the educational process contribute to the intercultural competence development, to recruit employees who will be able to operate successfully in a multicultural hospitality environment.
\end{abstract}

\footnotetext{
${ }^{23}$ aleksandra.grobelna@gmail.com
} 
The study problem is discussed in the context of literature review and the previous research conducted in the hospitality setting. Implications for practitioners and educators are also delivered.

Key words: challenges, management, hospitality environment.

\section{Hospitality industry in a multicultural perspective}

The term "culture" may have a variety of meanings used in different contexts [Nicholls 2011, p. 211]. Generally, beliefs, a way of life, customs which are shared and accepted by people in a given society is what the culture reflects. Culture provides an individual with an awareness of his/her identity, roots, historical background, giving also a sense that one belongs to a certain community [Luka et al. 2013, p. 3]. It regulates and controls an individual's attitudes and behaviors [Choi and Kim 2013 , p. 22]. Culture is shaped by many forces, among which religion, political power distribution, strong and charismatic leaders, historians and story tellers are indicated [Poprawski 2009, pp. 31-32].

However, problems may occur when people from different cultural backgrounds misunderstand each other, which results not only from language barriers but is also due to cultural differences. Thus it is important not only to speak the foreign language but also be aware of cultural differences which exist in different countries [Luka 2013, p. 2].

Given the international nature of the hospitality industry, cultural awareness and intercultural communication have become very important, both in relations with hotel guests and hotel employees. There are several reasons which justify why today's hotel professionals should be aware of these interactions and the possibilities of managing them.

First. Experiencing cultural differences is perceived as one of the most fundamental motivators for traveling [Steiner and Reisinger 2004]. Over decades, tourism has experienced the continuing growth and diversification becoming one of the fastest growing economic sectors in the whole world [http://www2.unwto. org/content/why-tourism]. nternational tourist arrivals grew by $4.4 \%$ in 2014 to 1.135 billion, and UNWTO forecasts a continuing growth in international tourist arrivals [http://www2.unwto.org/content/why-tourism].

In 2014, Poland was visited by 16 million foreign tourists, which is $1.3 \%$ more compared with the previous year [Charakterystyka przyjazdów... 2015, p. 1]. In 2013, 5.2 million foreign tourists visiting Poland stayed in tourist accommodation establishments, mainly in hotels and similar establishments [Turystyka w 2013 r., p. 141]. These visitors were of different nationalities and socio-cultural backgrounds [Turystyka w 2013 r., p. 52].

Given the growing foreign tourists arrivals, it is obvious that interpersonal interactions between individuals of different nationalities and cultures are likely to 
continue. Thus to operate successfully hospitality professionals should understand and empathize with people from different cultural backgrounds.

Second. Many hotel chains are seeking expansion opportunities into overseas markets [Hu et al. 2002, p. 31]. The Accor Hotels, for example, as an international hotel group operates globally and has hotels in numerous capitals and major cities throughout the entire world [www.accorhotels-group.com/en/franchiseand-management/our-contracts/our-franchise-contract.html]. Thus moving to a different country for an international assignment is possible when working for a global hotel group. However, the global expansion of hospitality companies may cause that hotel managers are sent by their organizations to fundamentally different culture destinations than their home environment [Weber and Ladkin 2010, p. 412]; they are often transferred overseas, where they are immersed in a foreign culture immediately [see Taylor and McArthur 2009, p. 6]. Thus, given the global nature of the hospitality industry, hospitality managers need to be flexible in the context of a geographical location [Jenkins 2001, p. 19] and have to adjust to the new living environment and business operations in a given country. They need to be aware that other employees may not share their language or cultural background. Therefore, to be successful and manage with clarity and impact, the proficiency in the target language and some experience in the culture where they will be working is essential. For example, in a study by Wei-Tang (T.) Hu et al. [2002, p. 36], the majority of study respondents (expatriate hotel employees) agreed that learning three things was important to understand the business operations in Taiwan: the philosophy of gift giving and receiving, the Taiwan business protocol, and the business language.

Third. Continued globalization is increasingly resulting in cultural diversity of the hospitality workforce [Weber and Ladkin 2010, p. 411]. One of the worldwide operating hotel chains - the Hilton Worldwide - claims that "with more than 300,000 owned, managed, franchised and corporate Team Members across more than 93 countries, we are by nature diverse"[ http://jobs.hiltonworldwide.com/en/whychoose-us/workplace-diversity/culture/?cntry=united-states]. Whereas the Accor hotel group, indicates that they employ 180,000 workers in more than 92 countries and offer almost 100 professions across 5 continents [http://www.accorhotelsgroup.com/en/recruitment-and-careers.html]. As a result, many cultures have to work together and communicate during daily duties. This cooperation and communication is critical in the hospitality business where customers are served by many employees, who in turn have to be supported by other staff [Choi et al. 2013, p. 411]. Bill Faulkner and Anoop Patiar [1997, p. 104] underline that to serve guests and resolve their problems, contact employees are usually required to communicate with staff from other areas. If cooperation between departments fails due to cultural differences and communication misunderstandings - contact employees may not be able to function effectively, especially when service failures occur and 
an immediate recovery action is needed. This "moment of truth" may negatively influence customers' service experience, leading to guests' dissatisfaction and even their decision to leave.

Fourth. Well-managed human resources are the key to company effectiveness and competitive advantage. In the hospitality industry, which is labor-intensive, human resource management is more complex [Casado 2001, p. 29] and strongly depends on effective communication [Wolvin 1994, p. 195]. However, lack of understanding of cultural differences may lead to many communication misunderstandings and ineffective practices in managing, motivating and rewarding culturally diverse employees [Lee and Chon 2000, p. 126], which in turn may result in employees' job dissatisfaction and frustration. When employees' frustration grows, turnover may increase and product and service quality suffer [LeBlanc et al 1995].

Summing up, in light of a growing number and intensity of intercultural interactions, well-developed intercultural competence is very important to function effectively with people from different cultures [Seymour and Constanti 2002, p. 3]. This means an ability to see and understand differences between one's own and other persons' cultures and countries, accepting them and reacting accordingly in both conversation and behavior [Luka et al. 2013, p. 3]. Culturally competent individuals should have a great mixture of attitudes, knowledge and skills that support them to establish good relations and communicate effectively with representatives of different cultures [Taylor and McArthur 2009, p. 6].

\section{Cross-cultural service encounters as a source of challenges for the hospitality industry}

Numerous service firms strongly rely on their employees to satisfy customers [Lee-Ross 2003, p. 263]. It is said that thanks to their special talents and abilities to provide high service quality, employees play a key role in gaining competitive advantage [Baron and Armstrong 2008, p. 39]. This is strongly observed in the hospitality industry which is called "people industry" [Kim et al. 2007, p. 421], where hotel services are delivered to people through people [Piasta 2007, p. 326] and the way in which guests are treated directly informs them how important they are for the organization [Martin 2006, p. 63].

However, given the global nature of the hospitality industry [Jenkins 2001, p. $19]$ and the increasingly cross-cultural nature of consumption in hospitality services [Nicholls 2011, p. 209], employees, every day experience cross-cultural interactions with others, which require from them to be aware of the wide range of different customs and cultures [Taylor and McArthur 2009, p. 6]. Theme more that, a variety of hotel guests from different social and cultural backgrounds may contribute to increasing communications problems and other misunderstandings [Faulkner and Patiar 1997, p. 111], especially that guests from different cultures may have 
different preferences and expectations of hoteliers [Torres et al. 2014, p. 260] and may perceive hotel services in different manner.

For example, Edwin N. Torres et al. [2014, p. 260] in their study conducted among hotel guests of different nationalities visiting the Central Florida area showed that although there are some universal service elements, guests from different cultures can also be delighted by different services and amenities. Whereas Scott R. Swanson et al. [2014, pp. 56-63] provided a cross-cultural comparison of Chinese and American hospitality customers and proved that cultural differences may affect the types of critical incidents reported by customers, recovery approaches and even customers' post-incident behaviors.

On the other hand, Nick Johns et al. [2007, p. 155] proved that individuals' predispositions to deliver good service may also be influenced by their ethnic or national culture. Therefore it may be said, that the hospitality industry often depends on both multicultural guests and multicultural workforce [Johns et al. 2007, p. 147]. A service encounter between customers of one culture and employees of another one may result in many misunderstandings and conflicts due to different cultural values and norms [Sizoo et al. 2003, p. 74; Sizoo et al. 2010, p. 10]. The consequences for organization effectiveness may be very serious, such as unhappy customers, frustrated employees and finally the loss of business [Sizoo et al. 2003, p. 74].

Thus, understanding guests' worldviews and cultural-specific needs is strongly needed to decide what kind of service response is the most suitable in a given service situation. It is vital to remember that what delights customers from one culture might not delight others, thus it is important to target various guest groups appropriately, delivering services and amenities according to their preferences [Torres et al. 2014, p. 260]. In this way guests are provided with truly "cultureoriented" service experience, which may lead to their satisfaction and further loyalty.

Summing up, due to the that a service encounter is perceived as the most important determinant of service quality [Johns et al. 2007, p. 147] and customers and employees are strongly affected by each other [Jiang and Tribe 2009, p. 9], challenges for human resources management increase. Hospitality industry has always been perceived as an industry of diverse cultures [Suh et al. 2012, p. 110] where effective communication is pivotal to operate successfully in the multicultural surrounding.

\section{Managers in the multicultural hospitality business - communication challenges facing the entry level leaders}

The importance of effective communication is well recognized today and its role cannot be overemphasized especially in the hospitality setting, where improved communication has been identified as the key to quality, productivity and competitiveness [Wolvin 1994, p. 195]. "Dealing with people is one of the biggest 
challenges a manager has to face" and communication is often one of the most difficult areas [Kavanagh 2002, p. 22]. Miscommunication may strongly influence business effectiveness, including the loss of prestige, credibility, ultimately leading to financial and other business problems [Lasiński 2000, pp. 19-20].

Literature indicates that $80 \%$ of a hospitality manager's time is spent on communicating activities to hotel guests, peers, superiors and, the most frequently, to subordinates [Lolli 2013a, p. 295; Lolli 2013b, p. 356]. Many argue that interpersonal communication is a pivotal skill for leaders to be successful [Lolli 2013a, p. 297]. Effective communication is a key to successful management of human resources and communication practices are among the most powerful tools for improving organizational effectiveness [Brownell 2003, p. 46].

However, culture and communication are strongly interconnected [Kiełbasiewicz-Drozdowska and Radko 2006, p. 76]. In the face of the diversity of the hospitality workforce from varied ethnic, generational, socioeconomic and educational backgrounds [Lolli 2013a, p. 297], the main barriers in effective communication can be created by cultural and language differences that exist in the industry [Lolli 2013b, p. 359]. Therefore, hospitality mangers must make a great attempt to integrate the various cultures and proactively synchronize their operational environments with their subordinates' specific needs, values and lifestyles to achieve high organizational performance and set goals.

Communication and the language in which it is conducted have a great meaning [Poprawski 2009, p. 33]. Functioning in a global and competitive hospitality setting managers require "the language of leadership", which instills confidence, motivates and inspires [Brownell 2003, p. 44]. Especially when dealing with multicultural staff, they need to be efficient by making their ideas clear and mobilizing all around to achieve common goals and objectives [Lolli 2013b, p. 358]. However, facing the workforce diversity, a need for deliberate and careful communication planning is stressed to ensure that intended meanings are precisely understood by the target audience [Brownell 2003, p. 43]. If the language is used ineffectively, managers' knowledge cannot be put to use in accomplishing their goals [Brownell 2003, p. 42]. Moreover, due to ineffective interpersonal communication, employees may feel unmotivated, confused, unappreciated and frustrated, which may contribute to their leaving [Lolli 2013a, p. 295].

Using literature review and personal interviews with executive-level leaders in the hospitality industry, Jeffrey C. Lolli identified interpersonal communication skills used by leaders when dealing with various constituents at varying levels and categorized them into four main components: listening, body language, verbal language, and conduct [Lolli 2013a, p. 296, Lolli 2013b, pp. 359-360]. However, the problem is that many talented managers with expertise in their field may not be successful just due to the lack of the ability to communicate effectively [Brownell 
2003, p. 41]. This problem seems to touch particularly the entry-level managers. Although effective communication skills are among major competencies needed by hospitality and tourism management graduates [Mayo and Thomas-Haysbert 2005, p. 13], the results of Lolli's studies [2013a, p. 297; 2013b, p. 364] conducted among young hospitality leaders showed that graduates tend to be deficient in their communication skills as entry-level leaders and feel to be underprepared to be competent communicators, including communication with diverse workforce. Among many study results, the entry-level leaders perceived themselves to be the least prepared in "demonstrating appropriate cultural communication skills", and the importance of this skill was rated by them as higher than the level of their preparedness [Lolli 2013b, p. 363].

In the case of Poland, according to a report for Ministry of Sport and Tourism [Losy absolwentów szkół i uczelni kształcących kadry dla turystyki..., 2014], tourism and hospitality employers mostly agree that graduates are prepared to work in the industry at an average level (40\%), whereas 16\% of them deem the graduates not prepared at all. Among the most important assessment criteria, the language and communication skills were indicated. This may worry the more so that in a study by Ineta Luka et al. [2013, p. 12, 25], among skills and abilities which develop intercultural competence, both students and tourism employers considered as the most important: language skills, an ability to work in a multicultural team, an ability to communicate with clients and colleagues.

However, the above mentioned problems create a serious challenge for hospitality educators, as they are responsible the most to provide a multicultural industry with hospitality professionals who will be able to achieve successful interactions both with their employees and with guests from different cultural backgrounds.

\section{Intercultural challenges in hospitality industry-implication for education}

Taken the international nature of the hospitality industry, educators have a responsibility to assist students in becoming qualified managers, also for overseas assignments [Hu et al. 2002, p. 40]. The more that there are students who regard an international career in tourism in the context of working abroad or working for an international corporation [e.g. Hjalager 2003, p. 28, 31]. Thus, students should acquire the skills to recognize the impact of cultural differences before they graduate to avoid difficult situations which may potentially happen due to their lack of sensitivity to cultural differences [Suh et al. 2012, p. 110].

In spite of the fact that hospitality management degree programs should provide future managers with the necessary skills to operate in an increasingly international industry and prepare them to successfully manage in the context of its cultural diversity [Seymour and Constanti 2002, p. 3], there are study results [e.g. Taylor and McArthur 2009, p. 13], which show that hospitality management students 
were quite weak in their knowledge of culture (food and customs) and may not be prepared sufficiently to enter the globalized hospitality work environment.

In face of this fact, development of students' intercultural competence is crucial and has to be strongly facilitated by well-prepared university tourism and hospitality programs. Curricula which aim to reinforce students' intercultural competence should include tourism specialization courses, language courses and students' internships (practical working experience) [Luka 2013, p. 5]. This educational approach should give students an opportunity to gain and develop cultural knowledge, experience, awareness, and sensitivity, which are all strongly required to communicate and work effectively across cultures [Taylor and McArthur 2009, p. 7]. Figure 1 illustrates the point.

In their efforts, educators should remember that to understand the cultural differences and to make a comparison between cultures, students need to understand their own culture first, which may influence their ability to draw parallels between cultures, see and create associations, and thus support a better understanding of other cultures [Luka et al. 2013, p. 4].

Figure 1. Tourism and hospitality management degree study programs in the context of students' cultural competence development

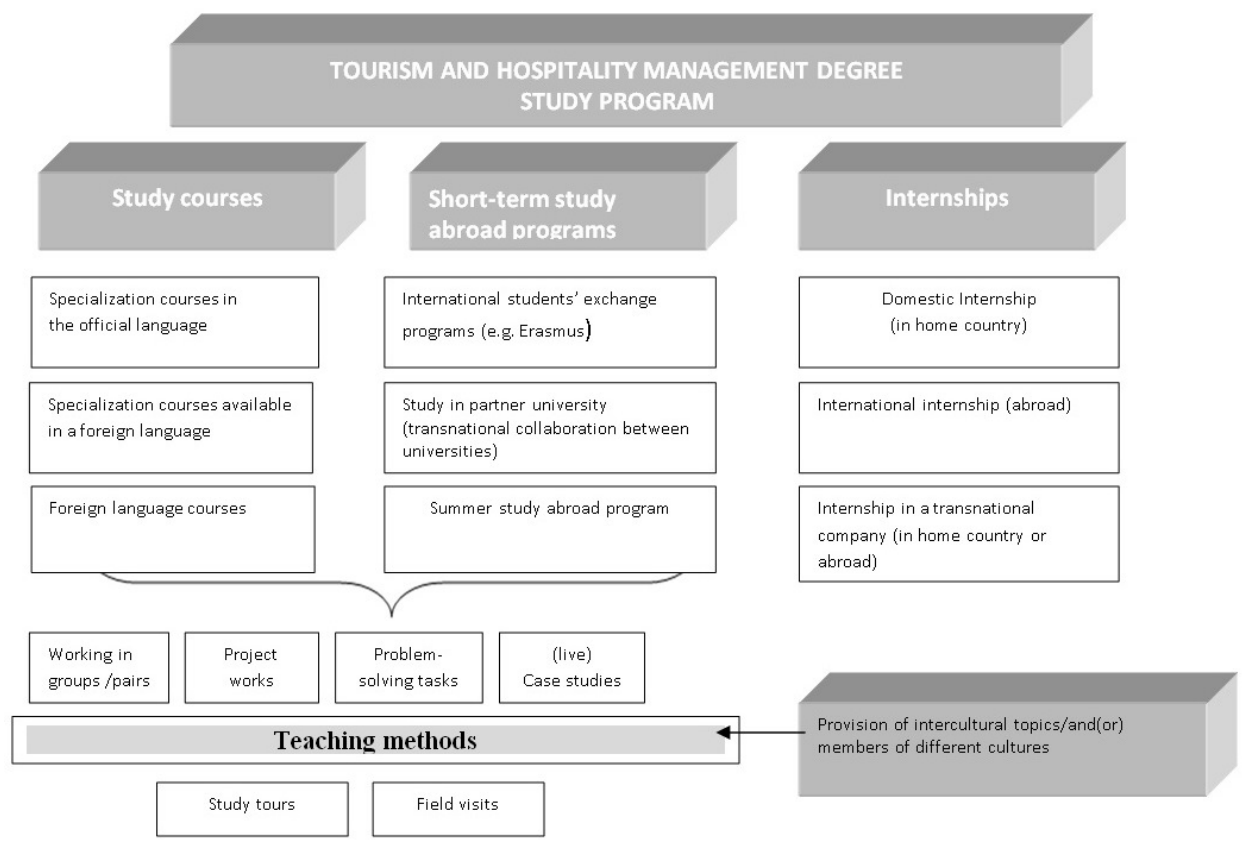

Source: own work based on: Hjalager 2003; Luka et al. 2013; Yao-Yi 2015; Ruhanen et al. 2013; Jenkins 2001, Mancini-Cross et al. 2009; Taylor and McArthur 2009; Lolli 2013 a. 
Taking into account the above, the following recommendations for educators have been formulated:

First. Beside the usual core subjects, the curricula should include various tourism specialization and foreign language courses, through which students should have a possibility to acquire knowledge and learn about different countries, their traditions, cultural values, traditional cuisine, religions, folk, business etiquette, etc. and have a chance to discuss problems actually facing foreign countries and different cultures [Luka et al. 2013, p. 23].

Second. Educators should align theory and practice more closely and adapt their teaching methods to offer students an approach which would involve more "real-life practice" [Rodriguez-Anton et al. 2013, p. 27] and facilitate students" development, especially in cooperation and communication skills [Luka 2013, p. 18]. Thus different teaching methods should be applied, such as case studies, group and team work, pair work, project work, etc. [Luka 2013, p. 18]. Other forms, such as role playing, simulations or videotaping supported by later feedback are also proposed [Lolli 2013a, p. 297]. Additionally, educators should attach a high level of importance to interactions between students from different cultures during such learning activities. Thus providing team members from different nationalities and ethnic cultures is strongly recommended, as it may give a unique opportunity to review the problems from the point of view of different nationalities and discuss, compare or analyze the experience of different cultures in a relevant field [Luka 2013 , p. 18, 22].

However, the following questions may arise: are home students prepared to work effectively with international students? Can they see benefits that might be derived from working in multicultural groups? How are interactions between home and international students perceived by both sides? The study results by Seymour and Constanti [2002, pp. 8-10] showed that some problems may exist in these issues and there is a need for training and coaching in cross-cultural team-working skills, both for students and for staff [Seymour and Constanti 2002, p. 11].

Third. Practical working experience through a possibility to contact and interact with people from different nationalities and cultures is crucial for students' intercultural competence development. Practical working reflects a period of employment in the industry [Busby and Gibson, 2010, p. 4] when students are exposed to real working life [Solnet et.al. 2007, p. 67] to receive training and gain invaluable job experience in a given field of their future career interest [Zopiatis and Theocharous 2013, p. 34]. After practical training students should gain a better understanding of the industry specifics [Jiang and Tribe 2009, p. 10]. Students of tourism and hospitality management programs should have an opportunity to take an internship abroad and/or in a transnational corporation gaining intercultural experience through meeting and interacting with people from different national 
and cultural backgrounds and learning from social interactions with them. It is said that the more such opportunities students have, the more knowledge of intercultural differences they posses and the more open and tolerant they become, developing their intercultural competence [Luka 2013, p.18] which can be constantly updated [Yao-Yi 2015, p. 13]. Therefore, both a variety of times and forms of such experience should be provided as the study progresses.

An opportunity for students to visit different destinations deserves special attention, as it gives them a great possibility to truly interact and communicate with representatives of different cultures both in their own cultural surrounding and in their real-life situations. Experiences of other cultures often prompt individuals to reflect on their own culture [Yao-Yi 2015, p. 15], and thanks to a closer contact, it may be recognized that the first impression of the culture was sometimes misleading [Luka et al. 2013, p. 4]. Moreover, direct experience of other cultures may help students to recognize and understand even the slightest cultural nuances which may be difficult to teach and explain in the classrooms. For managers, understanding these nuances is crucial for establishing the workplace policies and resources that recognize the cultural value of staff members [Perry 2006, p. 78]. Finally, students have a chance to hear and become acquainted with different language accents and have a possibility to hear the English language which is spoken by people of different nationalities [Luka et al. 2013, p. 23], which may help them to avoid further misunderstandings when working with non-native employees, particularly that many members of the hospitality workforce worldwide speak English as a second language [Suh et al., 2012, p. 110], and they may bring their unique communication style, shaped by many factors (e.g. family, education, culture) to using English as a second language [Do you know that you have a unique communication style?..., 2015].

However, Fu Yao-Yi [2015, p. 15] underlines that to design an effective learning experience that promotes intercultural competence, understanding the key factors that contribute to students' development of this competence should be perceived by educators as first. Therefore, in a study conducted among students who participated in a global service-learning course in Kenya, the author discussed factors such as contrast between the two cultures and languages, intercultural competence of visitors and local people, the amount and quality of interaction with local people, as well as the length of the program and housing arrangements as those which seems to contribute to the development of students' cultural competence [Yao-Yi 2015, pp. 12-14]. Among many results it was shown that challenges and hardships that students observed during their stay in Kenya caused reflection on their own values and behavior and developed more empathy and respect toward the local people [Yao-Yi 2015, p. 13]. The contrast between the two cultures and languages seemed to be an important factor promoting the students' development of intercultural competence [Yao-Yi 2015, p. 15]. 
In a study by Taylor and McArthur [2009, p. 12] as the most useful experience for learning about other cultures students indicated spending some time in another country (as tourists, undertaking jobs/internships abroad, participating in foreign study programs) and conversing with others who had spent time abroad (friends, family members, classmates). Electronic media as well as eating at ethnic restaurants and studying a foreign language were also indicated.

Summing up, hospitality students should be exposed to a wide variety of different nationalities and cultures from the beginning of their study. Social experience gained through contacting and interacting with such people has a great meaning, thus through many activities (Fig. 1), such as participation in students' exchange programs (e.g. ERSMUS), cooperation with foreign partner educational institutions, and international internships, educators should create real possibilities for students to gain experience in international environments representing diverse cultures and traditions. Following Yvette Reisinger and Lindsay Turner [1998, p. 175], "social contact with a culture different from one's own (...) can be an intensely rewarding cultural and learning experience".

\section{Intercultural challenges in hospitality industry - implication for business}

Given the international nature of the hospitality industry, organizations that will be unable to successfully accommodate to cultural diversity of both their markets and workforce will be left behind. Hospitality companies need to understand the uniqueness of their global workforce and recognize cultural differences as a source of their business success.

Thus, employees should be primarily viewed as the asset that constitutes value to service firms [Casado 2001, p. 28]; they should be treated as humans with their own feelings, aspirations, personal goals, and priorities in life, etc. [Gursoy et al. 2008 , p. 449]. As literature stresses, major hospitality companies understand that human resources are significantly different than other company resources [Gursoy et al. 2008, p. 449]. Many of them seem to be strongly aware of cultural diversity of their workforce, which they value and promote. For example:

- The IHG states that: "IHG is filled with great people. People from different countries and cultures, speaking different languages, driving our company forward around the globe. They make us who we are, so we give them every opportunity we can" [http://careers.ihg.com/about-ihg].

- The Ritz-Carlton underlines: "The Ritz-Carlton fosters a work environment where diversity is valued, quality of life is enhanced, individual aspirations are fulfilled (...)" [http://www.ritzcarlton.com/en/Corporate/GoldStandards/ Default.htm].

- The Marriott International declares that: "Marriott promotes the recruitment, retention, and advancement of diverse employees (...)" [http://www.marriott. $\mathrm{com} /$ diversity/diversity-and-inclusion.mi]. 
- The Hilton Worldwide points out: "Our priority is to understand and embrace unique global cultures to ensure that our Team Members are seen, heard, valued and respected (...)" [http://jobs.hiltonworldwide.com/en/why-choose-us/ workplace-diversity/culture/?cntry=united-states].

The growing awareness of diversity and its value should be communicated through the company, implemented into organization's strategic goals and core organizational values. It should also be promoted in every area and at every level of the hospitality business.

However, without proper training and clear communication employees who face cultural diversity may feel confused and uncertain, which may influence internal operations, customer service and finally guests' satisfaction. Therefore, it is vital to generate and reinforce an awareness of cultural diversity among hospitality employees through many training and inclusion programs as well as additional initiatives (e.g. celebrating international traditions and customs as in the case of the Hilton Worldwide] [http://jobs.hiltonworldwide.com/en/why-choose-us/ workplace-diversity/culture/?cntry=united-states]. These activities should help employees to recognize and understand the specific views of others and support trust and respect towards representatives of different cultures. Through openness and exposure to culturally diverse points of view, many may feel inspired to propose novel, useful and culture-oriented service solutions. In this way "diversity enriches a hospitality organization by adding new cultures, ideas and alternative methods for solving problems" [Lee and Chon 2000, 126]. The e-learning course Diversity, Inclusion \& You by the Hilton Worldwide [http://jobs.hiltonworldwide.com/en/ why-choose-us/workplace-diversity/?cntry=united-states] could be an example, as one providing a number of valuable benefits and tools for employees working in a diverse environment.

The hospitality industry also strongly relies on their managers' ability to be service-minded and focused on guests [Scott-Halsell et al. 2011, p. 4]. However to provide guests of different cultures with outstanding service experience managers should consider testing for and training in intercultural sensitivity of employees who are involved in cross-cultural service encounters as they provide their foreign customers with better service and their organizations with better results [Sizoo et al. 2003, p. 74]. Steve Sizoo et al. [2003] showed in their study that interculturalsensitive employees are more attentive to customers' from other cultures needs; contribute to generate more revenue per foreign customer; their interpersonal skills are more appropriate in a multicultural workplace, they are also more satisfied with their jobs and get more satisfaction from interacting with foreign customers [Sizoo et al. 2003, p. 74] Additionally, providing employees with training with linguistic tools to communicate successfully with customers from a range of cultures is recommended [Nicholls 2011, p. 218]. Moreover, employees should also skillfully 
adapt the style in which they communicate to the intercultural contexts in which they find themselves.

Summing up, to manage successfully in the global hospitality business, both the recognition and promotion of the uniqueness of the diverse workforce is needed. However, culture-oriented managerial practices must be undertaken to create competitive advantages based on different people (employees) whose performance significantly influences the guests' hospitality experience.

\section{Directions for future research}

The awareness of the existence of many cultures and the ability to understand them is one of the main factors which determine the effectiveness of the hospitality business and should be the focus of future research that may take various directions:

First. The commonalities and differences which exist between cultures are perceived as important to understand consumer behavior and perceptions in the hospitality industry [Nicholls 2011, p. 209]; however, there is still little information on the importance of the impact of culture on customer expectations in the hospitality industry [Taylor and McArthur 2009, p. 6, 8]. Therefore, investigating expectations of guests from different cultural backgrounds of hospitality services, especially when visiting Poland, could be very interesting for hotel operators to understand the cultural diversity of their markets expectations and to adapt services accordingly.

Second. Managers should also be aware that interactions between customers from different cultures may potentially influence customer service experience and satisfaction; therefore, empirical research in this issue is required, especially that customer-to-customer interaction has rarely been studied in a cross-cultural context and the lack of such research in the case of the hospitality industry seems to be particularly surprising [Nicholls 2011, p. 209, 220].

Third. To ensure the Polish hospitality business with well-qualified managers, it seems to be important to identify the key managerial competencies needed for future leaders to operate effectively with people from different cultural backgrounds. Comparing educators' and business perspectives of this issue may be helpful to identify potential gaps and formulate recommendations for both education and its partnerships with business.

Fourth. Polish hospitality students' perspective should also be taken into empirical account. As a starting point for educational improvements, it is especially crucial to investigate how they feel to be prepared to work in a multicultural environment and what aspects of their study programs particularly facilitate or hinder their intercultural competence development. 


\section{Summary}

This paper showed a wide range of ways in which the term of "cross-cultural" interactions can be perceived in the hospitality industry creating challenges for the business and education. Well- defined study programs should give students a real opportunity to gain knowledge of other cultures and cultural differences and to develop language and communication skills and abilities to work in a multicultural environment. Especially experience of other cultures may significantly influence intercultural competence development, which is vital for their careers [Yao-Yi 2015, p. 8].

In conclusion, appreciation and respect for multicultural diversity and a good understanding of cultural differences is the starting point to manage effectively diverse employees and to provide (through them) diverse guests with excellent service enriching their cultural experience. However, hospitality organizations need to be aware that service encounters should be skillfully tailored to the specific needs of the guests from different cultural backgrounds. When hotel services interact with customers' culture and are provided in a culture-acceptable manner, then service experience may be strongly enriched. Such a culture-oriented approach may become a source of competitive advantage, as the Marriott group underlines, "Embracing differences is part of the way we do business around the world, and essential to our success (...)" [http://www.marriott.com/diversity/diversity-andinclusion.mi].

\section{References}

Busby G.D., Gibson P. (2010), Tourism and hospitality internship experiences overseas: A British perspective, "Journal of Hospitality, Leisure, Sport and Tourism Education", 9(1), pp. 4-12.

Lasiński G. (2000), Sžtuka prezentacji, Poznań: Wyd. eMPI².

Solnet D., Robinson R., Cooper Ch. (2007), An Industry Partnerships Approach in Tourism Education, "Journal of Hospitality, Leisure, Sport and Tourism Education", 6(1), pp. 66-70.

Baron A., Armstrong M. (2008), Zarzadzanie kapitatem ludzkim. Uzyskiwanie wartości dodanej džieki ludziom, Kraków: Oficyna Wolters Kluwer Business.

Brownell J. (2003), Applied Research in Managerial Communication: The Critical Link between Knowledge and Practice, "Cornell Hotel and Restaurant Administration Quarterly", 44 (2), pp. 39-49.

Casado M. (2001), Theory of the effect of Compensation on turnover in hospitality companies, "Journal of Hospitality and Tourism Education", 13 (3/4), pp. 28-33.

Charakterystyka przyjazdón cudzoziemcón do Polski w 2014 roku; Ministerstwo Sportu i Turystyki, http://www.msport.gov.pl/statystyka-turystyka/charakterystyka-przyjazdowcudzoziemcow-do-polski-w-2014-roku, 03.07.2015.

Choi K.H., Kim D-Y. (2013), A cross cultural study of antecedents on career preparation behavior: Learning motivation, academic achievement, and career decision selfefficacy, "Journal of Hospitality, Leisure, Sport \& Tourism Education”, 13, pp. 19-32. 
Choi Y.G., Kwon J., Kim W. (2013), Effects of attitudes vs experience of workplace fun on employee behaviors: Focused on Generation Y in the hospitality industry, "International Journal of Contemporary Hospitality Management”, 25(3), pp. 410-427.

Do you know that you have a unique communication style?, http://sherwoodfleming.com/ do-you-know-that-you-have-a-unique-communication-style/, 05.07.2015.

Faulkner B., Patiar A. (1997), Workplace induced stress among operational staff in the hotel industry, "International Journal of Hospitality Management", 16 (1), pp. 99-117.

Gursoy D., Maier T.A., Chi C.G. (2008), Generational differences: An examination of work values and generational gaps in the hospitality workforce, "International Journal of Hospitality Management", 27(3), pp. 448-458.

Hjalager A-M. (2003), Global Tourism Careers: Opportunities and Dilemmas Facing Higher Education in Tourism, "Journal of Hospitality, Leisure, Sport and Tourism Education", 2(2), pp. 26-38.

http://careers.ihg.com/about-ihg, 05.07.2015.

http://jobs.hiltonworldwide.com/en/why-choose-us/workplace-diversity/ culture/?cntry=united-states, 05.07.2015.

http://jobs.hiltonworldwide.com/en/why-choose-us/workplace-diversity/?cntry=unitedstates, 05.07.2015.

http://www.accorhotels-group.com/en/recruitment-and-careers.html, 05.07.2015

http://www.marriott.com/diversity/diversity-and-inclusion.mi, 05.07.2015 http://www. ritzcarlton.com/en/Corporate/GoldStandards/Default.htm, 05.07.2015

http://www2.unwto.org/content/why-tourism, 05.07.2015

http://www2.unwto.org/content/why-tourism, 05.07.2015

Hu W-T. (T), Martin L., Yeh J-M.R. (2002), Cross-Cultural Impact and Learning Needs for Expatriate Hotel Employees in Taiwan Lodging Industry, "Journal of Human Resources in Hospitality \& Tourism”, 1(3), pp. 31-45.

Jenkins A.K. (2001), Making a career of it? Hospitality students' future perspectives: an Anglo-Dutch study, "International Journal of Contemporary Hospitality Management", 13 (1), pp. 1320 .

Jiang B., Tribe J. (2009), Tourism jobs - short-lived professions': Student attitudes towards tourism careers in China, "Journal of Hospitality, Leisure, Sport and Tourism Education", 8(1), pp. 4-19.

Johns N., Henwood J., Seaman C. (2007), Culture and service predisposition among hospitality students in Switzerland and Scotland, "International Journal of Contemporary Hospitality Management", 19(2), pp.146-158.

Kavanagh S. (2002), Could you be a team leader?, “Travel Trade Gazette”, 17 June, p. 22.

Kiełbasiewicz-Drozdowska I., Radko S. (2006), The role of intercultural communication in tourism and recreation, "Studies In Physical Culture And Tourism", 13(2), pp. 75-85.

Kim H.J., Shin K.H., Umbreit W.T. (2007), Hotel job burnout: The role of personality characteristics, "International Journal of Hospitality Management", 26(2), pp. 421-434. 
LeBlanc Ch.L., Mills K.E. (1995), Competitive advantage begins with positive culture, "Nation's Restaurant News", Oct 2, 29 (39).

Lee Ch., Chon K.-S. (2000), An investigation of multicultural training practices in the restaurant industry: the training cycle approach, "International Journal of Contemporary Hospitality Management”, 12(2), pp. 126-134.

Lee-Ross D. (2003), The quintessential relationship: service predispositions and quality assurance [in:] S. Kusluvan (Ed.), Managing employee attitudes and behaviors in the tourism and hospitality industry, pp. 263-275, New York: Nova Publishers.

Lolli J.C. (2013a), Interpersonal communication skills and the young hospitality leader: Are they prepared?, "International Journal of Hospitality Management”, 32, pp. 295-298

Lolli J. (2013b), Perceptions of the Importance and Preparedness of Interpersonal Communication Skills of the Entry-Level Hospitality Leader: Implications for Hospitality Educators, "Journal of Teaching in Travel \& Tourism", 13, pp. 354-373.

Losy absolwentów szkót i uczelni ksz̧tatcacych kadry dla turystyki, http://www.msport.gov.pl/ ksztalcenie-i-szkolenie-turystyka, 05.07.2015.

Luka I., Vaidesvarans S., Vinklere D. (2013), Educating Tourism Students for Work in a Multicultural Environment, "Journal of Teaching in Travel \& Tourism", 13(1), pp. 1-29.

Mancini-Cross C., Backman K.F., Baldwin E.D. (2009), The Effect of the Language Barrier on Intercultural Communication: A Case Study of Educational Travel in Italy, "Journal of Teaching in Travel \& Tourism", 9(1-2), pp. 104-123.

Martin W.B. (2006), Zarzqdzanie jakościq obstugi w restauracjach i hotelach, Kraków: Oficyna Ekonomiczna.

Mayo C.R., Thomas-Haysbert C. (2005), Essential competencies needed by hospitality and tourism management graduates as determined by industry professionals and hospitality educators, "Consortium Journal of Hospitality \& Tourism”, 9(2), pp. 5-17.

Nicholls R. (2011), Customer-to-customer interaction (CCI): a cross-cultural perspective, "International Journal of Contemporary Hospitality Management”, 23(2), pp. 209-223.

Perry P.M. (2006), Culture Clash, Restaurant Hospitality, August, pp. 74-78.

Piasta J. (2007), Marketing $w$ hotelarstwie, Warszawa: Jacek Piasta-Doradztwo.

Poprawski M. (2009), Leadership. An Intercultural Approach, "Journal of Intercultural Management", 1(1), pp. 28-41

Reisinger Y., Turner L. (1998), Cultural Differences between Mandarin-Speaking Tourists and Australian Hosts and Their Impact on Cross-Cultural Tourist-Host Interaction, "Journal of Business Research”, 42, pp. 175-187.

Rodríguez-Antón J.M., Alonso-Almeida M.. Andrada L.R., Pedroche M.C. (2013), Are university tourism programmes preparing the professionals the tourist industry needs? A longitudinal study. “Journal of Hospitality, Leisure, Sport \& Tourism Education”, vol. 12 (1), pp. 25-35.

Ruhanen L., Robinson R., Breakey N. (2013), A tourism immersion internship: Student expectations, experiences and satisfaction, "Journal of Hospitality, Leisure, Sport \& Tourism Education", 13, pp. 60-69. 
Scott-Halsell S., Blum S.C., Huffmann L. (2011), From school desks to front desks: A comparison of emotional intelligence levels of hospitality undergraduate students to hospitality industry professionals, "Journal of Hospitality, Leisure, Sport and Tourism Education", 10(2), pp. 3-13.

Seymour D., Constanti P. (2002), University Hospitality Education for International Management: A Case of Wasted Opportunities?, "Journal of Hospitality, Leisure, Sport and Tourism Education", 1(2), pp. 3-13.

Sizoo S., Iskat W., Plank R., Serrie H. (2003), Cross-Cultural Service Encounters in the Hospitality Industry and the Effect of Intercultural Sensitivity on Employee Performance, "International Journal of Hospitality \& Tourism Administration", 4(2), pp. 61-77.

Sizoo S., Serrie H., Shapero M. (2010), Succeeding in the global marketplace: A practical approach to developing the Cross-cultural skills of tourism \& hospitality students, "Journal of Tourism", XI (2), pp. 1-18.

Steiner C. J., Reisinger Y. (2004), Enriching the Tourist and Host Intercultural Experience by Reconceptualising Communication, "Journal of Tourism \& Cultural Change”, 2(2), pp. 118-137.

Suh E., West J.J., Shin J. (2012), Important competency requirements for managers in the hospitality industry, "Journal of Hospitality, Leisure, Sport \& Tourism Education", 11, pp. 101-112.

Swanson S.R., Huang Y., Wang B. (2014), Hospitality-based critical incidents: a cross-cultural comparison, "International Journal of Contemporary Hospitality Management", 26 (1), pp. 50-68.

Taylor M., McArthur L. (2009), Cross-Cultural Knowledge, Attitudes and Experiences of Hospitality Management Students, “Journal of Hospitality \& Tourism Education”, 21 (4), pp. 6-14.

Torres E.N., Fub X., Lehto X. (2014), Examining key drivers of customer delight in a hotel experience: $A$ cross-cultural perspective, "International Journal of Hospitality Management", 36, pp. 255-262.

Turystyka w 2013 r., http://stat.gov.pl/obszary-tematyczne/kultura-turystyka-sport/turystyka/turystyka-w-2013-r-,1,11.html, 05.07.2015.

Weber K., Ladkin A. (2010), Developing Effective Tourism Leadership, “Journal of China Tourism Research", 6, pp. 410-427.

Wolvin A.D. (1994), Communication in the hospitality industry, "International Journal of Hospitality Management", 13 (3), pp. 195-199.

www.accorhotels-group.com/en/franchise-and-management/our-contracts/our-franchise-contract.html, 05.07.2015.

Yao-Yi F. (2015), Factors that contribute to tourism students' development of intercultural competence, "Tourism”, 63 (1), pp. 7-17.

Zopiatis A., Theocharous A.L. (2013), Revisiting hospitality internship practices: A holistic investigation, "Journal of Hospitality, Leisure, Sport \& Tourism Education", 13, pp. 33-46. 